\title{
Impact of forest floor fire on soil carbon sequestration of Pinus roxburghii forest in Langtang National Park, Nepal
}

\author{
Biva Aryal ${ }^{1} \bowtie$, Bishnu Prasad Bhattarai ${ }^{2}$, Mohan Pandey ${ }^{1}$ and Anjana Giri ${ }^{3}$ \\ ${ }^{1}$ Society of Natural Resources Conservation and Development, Dillibazzar-33, Kathmandu, Nepal \\ ${ }^{2}$ Birendra Multiple Campus, Tribhuvan University, Chitwan, Nepal \\ ${ }^{3}$ Nepal Academy of Science and Technology, Kumaltar, Nepal \\ aryalbiva@yahoo.com
}

\begin{abstract}
Forest floor fires are known to be significantly important in carbon sequestration in soil. The present study investigated the total soil carbon stock (charcoal+soil organic carbon) and $\mathrm{CO}_{2}$ flux from four different depths $(0-2,2-10,10-30$ and $>30 \mathrm{~cm})$ in fired and unfired forest of $P$. roxburghii from Langtang National Park, Nepal. The aim of this study was to test the impact of forest floor fire on soil carbon sequestration. We measured total carbon stock in soil of unfired and fired sites of different intensities namely: high frequency and high intensity, high frequency and moderate intensity and high frequency and low intensity. There was significant difference $(P=0.00)$ of the soil organic carbon between the sites and different soil depths tested by one-way ANOVA. Similarly, one-way ANOVA test showed that soil charcoal stock was significantly different $(P=0.00)$ at different soil depths. The value of $\mathrm{CO}_{2}$ flux was increased with increasing volumetric water content and decreasing soil temperature. One-way ANOVA showed significant difference $(P=0.00)$ of volumetric water content, soil temperature and $\mathrm{CO}_{2}$ flux between the sites. In high frequency and medium intensity site, high amount of carbon sequestrated in soil suggested that fire of medium intensity mitigates high $\mathrm{CO}_{2}$ from the atmosphere.
\end{abstract}

Keywords: carbon stock, $\mathrm{CO}_{2}$ flux, $\mathrm{CO}_{2}$ mitigate, fire intensity, soil charcoal stock, soil organic carbon

\section{INTRODUCTION}

Soil carbon sequestration is a process in which $\mathrm{CO}_{2}$ is removed from the atmosphere and stored in the soil. This process is primarily mediated by plants through photosynthesis with carbon stored in the form of soil organic carbon. During forest fires, significant amount of $\mathrm{CO}_{2}$ is emitted to the atmosphere and simultaneously a fraction of the burning vegetation and soil organic matter is converted to black carbon which exists as a continuum of char and charcoal. In this way carbon is sequestrated in the form of SOC, charcoal, etc. in soil.

The amount of soil carbon depends on the above ground input received from leaf litter and on the decomposition of fine roots below ground (Rasse et al., 2006). The recycling of the plant's carbon in the soil system also depends upon macro and micro faunal activity and on litter quality (Hairriah et al., 2006). Carbon fixed within plant biomass ultimately enters the soil where it may reside for hundreds of years (Paterson et al., 1987). Soil carbon is an important 
part of the terrestrial carbon pool (Lal \& Kimble, 1997) and soils of the world are potentially viable sinks for atmospheric $\mathrm{C}$ and may significantly contribute to mitigation of global climate change (Lal et al., 1995; Bajracharya et al., 1998; Lal et al., 1998). Kirschbaum (2000) estimated that world's soil contain about $1500 \mathrm{Gt}(1 \mathrm{Giga}$ ton $=1015 \mathrm{~g})$ of organic carbon to a depth of $1 \mathrm{~m}$ and a further $900 \mathrm{Gt}$ from 1-2 m.

Fire plays a vital role and affects total carbon sequestration. Fire can influence the carbon cycle either by emission of $\mathrm{CO}_{2}$ to atmosphere during forest fire or conversion of forest biomass into char and charcoal. After fire, the incomplete combustion of plant material produces charcoal fragments of various sizes. Some of these fragments are incorporated into soils of the burn sites, while other fragments are carried away by wind or water, in some cases to later settle on the surface of a lake (Horn et al., 2014), adding to another long term carbon pool (Suman, 1984). The previous research suggested the importance of charcoal in soils and in sediments for the documentation of past fires and to understand long-term relationships between fire, climate, and human activity (Horn et al., 2000; League \& Horn, 2000; Sanford \& Horn, 2000; Whitlock \& Larsen, 2001; Berg \& Anderson, 2006; Hart et al., 2008). Charcoal stored in the soil also represents one of the way by which carbon is stored in the form of reservoir because charcoal does not easily recombine with the oxygen and form $\mathrm{CO}_{2}$ (Seiler \& Crutzen, 1980; Fearnside et al., 2001; Druffel, 2004; Schmidt, 2004). This charcoal is characterized by a high concentration of carbon and high resistance to natural degradation processes (Kuhlbusch \& Crutzen, 1995; Forbes et al., 2006; Foereid et al., 2011). Therefore, accurate information about the distribution of black carbon in soils is important for projections of future climate change.

Biological organisms have potentiality to capture and release atmospheric $\mathrm{CO}_{2}$ through photosynthesis, respiration and decomposition, respectively. Carbon dioxide released from soils in the process variably referred to as soil respiration, soil- $\mathrm{CO}_{2}$ efflux. The rate at which $\mathrm{CO}_{2}$ moves from soil to the atmosphere is controlled by the rate of $\mathrm{CO}_{2}$ production in the soil which mainly depends up on the soil properties (Raich \& Schlesinger, 1992). On a global scale, soil respiration in terrestrial ecosystem is estimated to contribute $50-75 \mathrm{PgC} / \mathrm{yr}$ (Houghton \& Woodwell, 1989). By comparison, fossil fuel burning adds $5 \mathrm{PgC} / \mathrm{yr}$ to the atmosphere (Marland \& Rotty, 1984).

Among the different forest types studied so far, P. roxburghii shows high sensitivity and resistivity against fire on forest floor (Paudyal, 2008; Kumar, 2015). It has been further justified because $P$. roxburghii forest in the study area showed negligible damage of tree due to fire (visual observation). Fire is always not destructive to the vegetation. It highly depends on the intensity of fire and types of fire i.e. forest floor fire or extensive fire. The destruction caused by extensive fire is more severe than forest floor fire. Until now there is no extensive fire recorded in the study area of $P$. roxburghii forest (park authorities). The nature of fire seems to be forest floor fire with different intensity because it only impacts on the ground vegetation without destroying the trees. It is therefore essential to study the amount of carbon stock in soil of $P$. roxburghii forest affected by different intensities of floor fire. With this background, the study has been focused on estimating the amount of charcoal in soils and SOC content while determining the total carbon stock in soil. Similarly, $\mathrm{CO}_{2}$ flux, volumetric water content and soil temperature were also analyzed. 


\section{MATERIALS AND METHODS}

\section{Study area}

Langtang National Park has an area of $1710 \mathrm{~km}^{2}$, and extends over parts of Rasuwa, Nuwakot and Sindhupalchowk districts in the southern mountainous terrain of the Nepal-China border. The park represents a meeting point between Indo-Malayan and Palearctic Realms, and holds rich biodiversity. It encompasses three distinct geographical zones: the Himalaya, the mid hill and basin (brochure of Langtang National Park). The sub-tropical vegetation is dominated by the Shorea robusta, Schima wallichii, Pinus roxburghii, Alnus nepalensis, etc.

The climate of the park is dominated by the southwest summer monsoon. Temperatures vary greatly due to the extreme difference in altitude in the entire area. Mean maximum temperature about $24.52^{\circ} \mathrm{C}$ during the June and mean minimum air temperature was $2.26^{\circ} \mathrm{C}$ in January. Most of the annual precipitation (80\%) occurs from June to September. Similarly meanmaximum precipitation was $593.45 \mathrm{~mm}$ in July, minimum in $6.6 \mathrm{~mm}$ in December (mean from 1999 to 2013, Department of Hydrology and Metrology, Nepal Government).

Langtang National Park of Rasuwa district, was the selected study area for this research. This district lies in between $27^{\circ} 55^{\prime}$ to $28^{\circ} 25^{\prime} \mathrm{N}$ latitude and $85^{\circ} 00^{\prime}$ to $85^{\circ} 50^{\prime} \mathrm{E}$ longitudes. According to the interview with park authorities, local people and also visual observation of forest fired conditions, the Pinus roxburghii forest of Dhunche (headquarter of Rasuwa District, $\left.28^{\circ} 6^{\prime} 42^{\prime \prime} \mathrm{N}, 85^{\circ} 17^{\prime} 52^{\prime \prime} \mathrm{E}, 2,030 \mathrm{~m}\right)$ and Syapru VDC (28`16'80.47"N, 85³2'90.87'"E, 1,352 m) were selected for the study. In these VDCs, the P. roxburghii forests located along the Trisuli river up to Pasang Lamhu Highway are frequently set on annual forest floor fire during the dry season (February-April). Small patches of unfired forest were located in the steep slope of upward of Pasang Lahmu Highway. Sites high frequency and moderate intensity and high frequency and low intensity are located in Dhunche VDC, while sites high frequency and high intensity and control were selected from Syapru VDC.

\section{Site selection criterion}

After discussion with the community, park authorities and visual observation, we decided to select key informants who have knowledge about the issues and an idea about the sites. Forest sites were surveyed with the help of local people to develop a basic understanding of geography as well as to establish rapport with them. According to them, Langtang National Park is prone to firing events annually. $P$. roxburghii forests were mainly fired once in a year with different intensity especially during the dry season. There were no extensive fire events in $P$. roxburghii forest of Langtang National Park (Park authorities). The fire mostly started from the forest floor continues up to middle of the tree trunks and leave the crown unaffected.After visiting the fire affected forest, three sites were classified on the basis of frequency (fire event within a time period) and intensity (fire severity) of fire and one site as a control. The sites were categorized as high frequency and high intensity site (HFHI), high frequency and moderate intensity site (HFMI), high frequency and low intensity site (HFLI), and a control (unfired) site (CON), after collecting the basic data of height of ground vegetation (Armour et al., 1984), charcoal accumulation on ground (Turcios et al., 2015), needle accumulations, fired level on tree trunks of Pine and other species (Fire science brief, 2009), presence of alive trees 
(James et al.,1985), coverage of bare land, number of burnt species, etc.

HFHI site:

Lowest (12\%) canopy coverage of graminoides.

Total ground coverage was low $(21.9 \%)$.

Remnant of burnt needles and bark on the ground, burnt stumps and even trunk of pine tree up to 4 meters (Fig.1a).

HFMI site:

Highest (34.5\%) coverage of graminoides.

Litter accumulation was highest (76\%) (fig.1b).

Regenerating young leaves on ground vegetation.

HFLI site:

Vigorously growth of understory (up to $2 \mathrm{~m}$ )

Shrub coverage was highest (87\%) (fig.1c).

CON site:

Highest (35\%) canopy coverage of graminoides (fig.1d).

Total ground coverage was low (21.9\%).

Almost no charcoal accumulation.

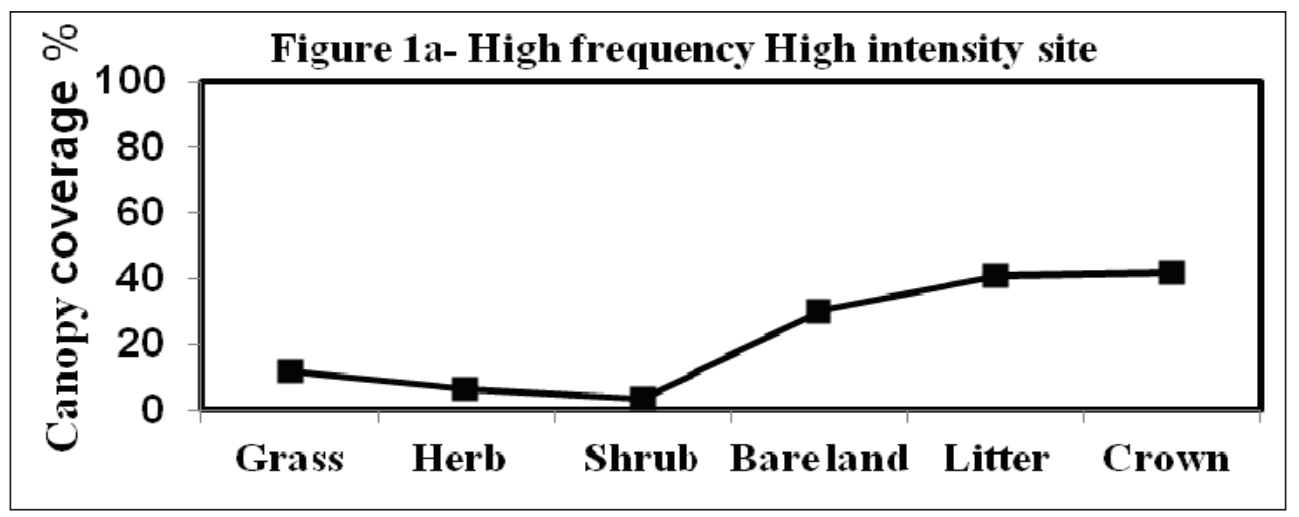

FIG. 1 Canopy cover (\%) of ground vegetation, bare land, litter and crown of high frequency intensity sites. 


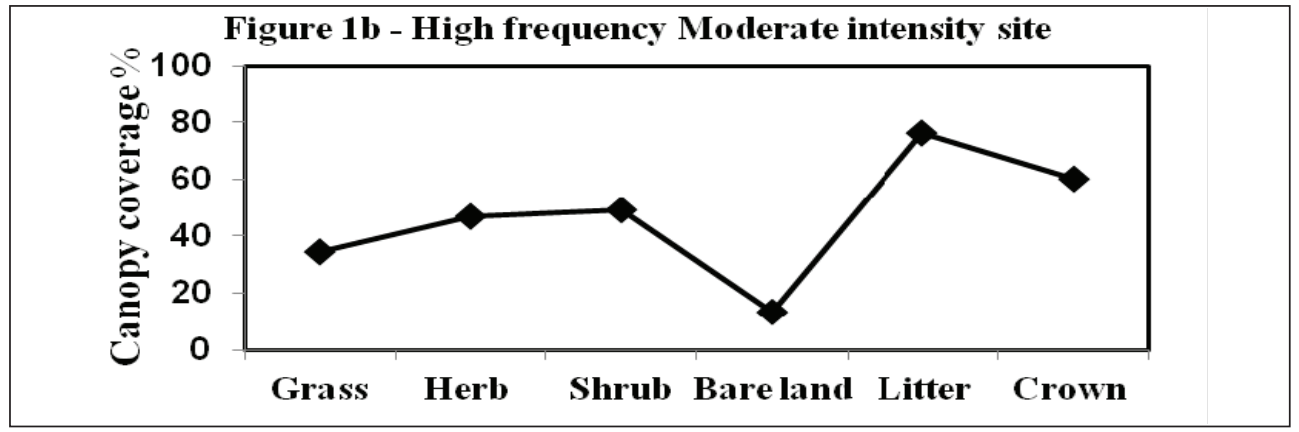

FIG. 2 Canopy cover (\%) of ground vegetation, bare land, litter and crown of high frequency moderate intensity sites.

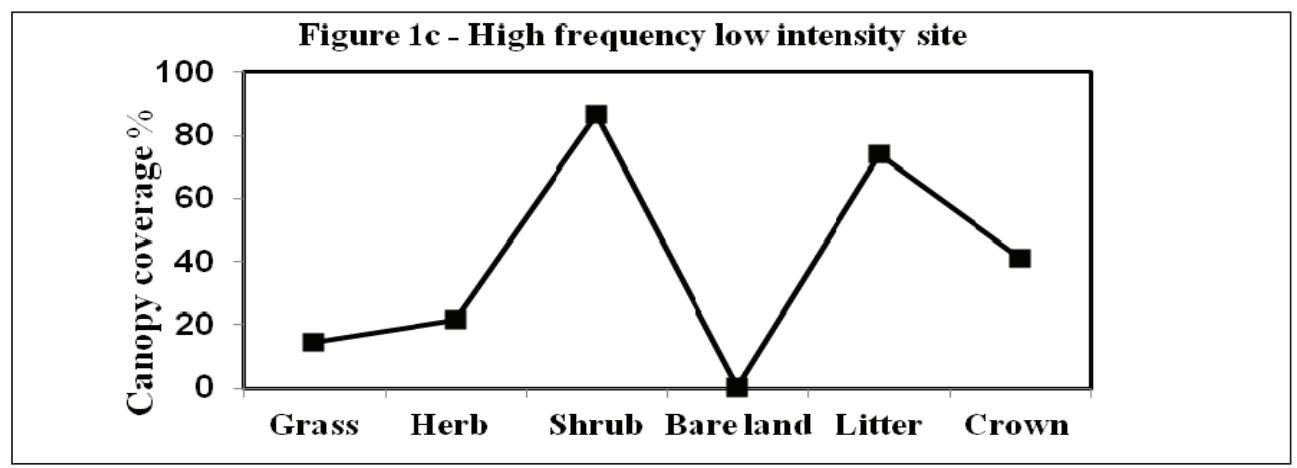

FIG. 3 Canopy cover (\%) of ground vegetation, bare land, litter and crown of high frequency low intensity sites.

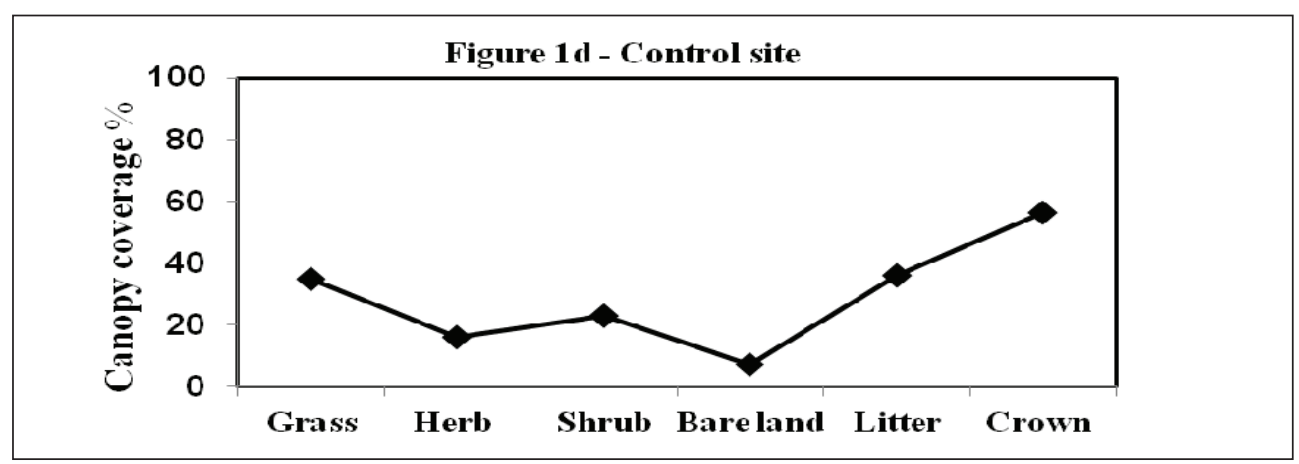

FIG. 4 Canopy cover (\%) of ground vegetation, bare land, litter and crown of control sites. 


\section{Soil sampling}

Altogether nineteen circular plots of $10 \mathrm{~m}$ were laid down in November-December 2015; five plots in each fired sites (HFHI, HFMI and HFLI) and four in control site (CON). Volumetric soil sampling was carried out by cores at four different depths $(0-2 \mathrm{~cm}, 2-10 \mathrm{~cm}, 10-30 \mathrm{~cm}$ and $>30 \mathrm{~cm}$ ) from the central and corner of each plot. Soils were collected from each soil depth for the estimation of grain size analysis, bulk density, soil pH, charcoal and SOC content.

Soil $\mathrm{CO}_{2}$ flux measurement

Soil $\mathrm{CO}_{2}$ flux measurement was determined by using portable gas analyser (EMG-4). Similarly, volumetric water content was measured by TDR-soil moisture meter and soil temperature was recorded by using hand held soil thermometer.

\section{Soil analysis}

Grain size analysis

Soil was sieved through different size sieve. Textural classes of the soils were determined following textural triangle of USDA system.

\section{Soil sample preparation and sorting of char}

The air dried soil samples were sieved through a mesh of $2 \mathrm{~mm}$. The material $>2 \mathrm{~mm}$ were sorted (e.g. charcoal, roots, coarse mineral fraction, barks, twigs, grass stems, cones and rocks) separately and weighed. About $50 \mathrm{~g}$ of air dried subsample was sieved through a $1 \mathrm{~mm}$ sieve and char was separated from the $1-2 \mathrm{~mm}$ and $<1 \mathrm{~mm}$ mineral soil fractions and weighed. The weight of all fractions - coarse fraction (mineral + coal $>2 \mathrm{~mm}$ was cleaned and dried)-fine roots gives the fresh fine soil. The air dried soil $<2 \mathrm{~mm}$ and charcoal $>2 \mathrm{~mm}, 1-2 \mathrm{~mm}$ and $<1$ $\mathrm{mm}$ were used for subsequent analysis and quantification of char distribution.

\section{Soil pH}

Soil $\mathrm{pH}$ was determined with a 1:2.5 soil water suspension using pH meter PHM 83 AUTOCAL.

Soil bulk density (BD)

Soil bulk density was determined using core sampling (Blake \& Hartge, 1986). Soil bulk density was analyzed according to Pearson et al. (2005).

3.5 Soil organic carbon (SOC) analysis

Soil organic carbon (\%) was analyzed in Kathmandu University, Dhulikhel, Kathmandu by Dry combustion method. SOC (t.ha-1) was calculated by Awasthi et al. ( 2005).

\section{$\mathrm{CO}_{2}$ mitigation (t.ha-1)}

$\mathrm{CO}_{2}$ mitigation was calculated by Bhattarai et al. (2012).

\section{Statistical analysis}

The significance of differences in BD, SCS, SOC between the sites and soil depths were evaluated by one-way ANOVA and Duncan's multiple range test by using SPSS software (SPSS Inc., Chicago, IL, USA). 


\section{RESULTS AND DISCUSSION}

\section{Soil texture class and soil pH}

Canopy cover of ground vegetation, bare land, litter and crown of different frequencies and intensities along with control sites are figured in fig. 1-4. The mean of CO2 flux, VWC (\%) and ST $\left({ }^{\circ} \mathrm{C}\right)$ of different sites and significant difference are shown in fig. 9 and total $\mathrm{CO} 2$ mitigation from different sites are figured in fig. 10.

Texture classes were similar in all investigated soil depths in HFHI site (sandy loam) as well as HFLI (sandy clay loam). However, in HFMI site, top soil $(0-2 \mathrm{~cm})$ was loamy sand type. Rest of the three depths was sandy loam type. Similarly, in CON site upper three depths were sandy clay loam and deep soil $(>30 \mathrm{~cm}$ ) was clay type (table 1). The pH data of the soil showed that there wasacidic soil in all sites. The highest value (6.21, i.e. slightly acidic) of $\mathrm{pH}$ was measured in CON site at top soil $(0-2 \mathrm{~cm})$. whereas the lowest values (5.02) was measured in $\mathrm{HFHI}$ at the depths of $10-30 \mathrm{~cm}$, followed by $2-10 \mathrm{~cm}$ and $>30 \mathrm{~cm}$ in HFHI site (table 1).

TABLE 1. Soil texture and $\mathrm{pH}$ in different sites and depths.

\begin{tabular}{|l|l|l|l|l|l|l|l|}
\hline Sites & $\begin{array}{c}\text { Soil } \\
\text { depth } \\
\mathbf{( c m})\end{array}$ & Silt (\%) & Clay (\%) & $\begin{array}{c}\text { Sand/ } \\
\text { Silt }\end{array}$ & $\begin{array}{c}\text { Silt/ } \\
\text { Clay }\end{array}$ & Texture & pH \\
\hline HFHI & $0-2$ & 20 & 13 & 3.4 & 1.5 & Sandy loam & 6.00 \\
\hline & $2-10$ & 18 & 14 & 3.8 & 1.3 & Sandy loam & 5.17 \\
\hline & $10-30$ & 17 & 20 & 3.7 & 0.9 & Sandy loam & 5.02 \\
\hline & $>30$ & 20 & 16 & 3.2 & 1.3 & Sandy loam & 5.17 \\
\hline & & & & & & & \\
\hline HFMI & $0-2$ & 17 & 14 & 4.1 & 1.2 & Loamy sand & 5.4 \\
\hline & $2-10$ & 18 & 15 & 3.7 & 1.2 & Sandy loam & 5.72 \\
\hline & $10-30$ & 17 & 19 & 3.8 & 0.9 & Sandy loam & 5.69 \\
\hline & $>30$ & 19 & 25 & 2.9 & 0.8 & Sandy loam & 5.70 \\
\hline & & & & & & & \\
\hline HFLI & $0-2$ & 20 & 25 & 2.8 & 0.8 & Sandy clay loam & 5.61 \\
\hline & $2-10$ & 22 & 27 & 2.3 & 0.8 & Sandy clay loam & 5.42 \\
\hline & $10-30$ & 23 & 25 & 2.3 & 0.9 & Sandy clay loam & 5.43 \\
\hline & $>30$ & 18 & 32 & 2.8 & 0.6 & Sandy clay loam & 5.52 \\
\hline & & & & & & & \\
\hline CON & $0-2$ & 18 & 22 & 3.3 & 0.8 & Sandy clay loam & 6.21 \\
\hline & $2-10$ & 17 & 20 & 3.7 & 0.9 & Sandy clay loam & 6.18 \\
\hline & $10-30$ & 18 & 21 & 3.4 & 0.9 & Sandy clay loam & 5.98 \\
\hline & $>30$ & 20 & 46 & 1.7 & 0.4 & Clay & 5.88 \\
\hline
\end{tabular}




\section{Soil bulk density (BD)}

The range of $\mathrm{BD}$ in $P$. roxburghii forest based on the profile $(0->30 \mathrm{~cm})$ depths as shown in fig. 5. There was gradual increase in the BD with the increasing soil depths. Mean minimum value $\left(0.55 \pm 0.05 \mathrm{gcm}^{-3}\right)$ was recorded in top soil of HFLI followed by HFMI, $\mathrm{HFHI}$ (fig.5). Similarly, mean maximum value $\left(1.07 \pm 0.11 \mathrm{gcm}^{-3}\right)$ was recorded in CON at the depths of $2-10 \mathrm{~cm}$, followed by CON $\left(1.03 \pm 0.15 \mathrm{gcm}^{-3}\right)$ at the depths of $10-30 \mathrm{~cm}$, and CON $1.02 \pm 0.13 \mathrm{gcm}^{-3}$ at the depths of $>30 \mathrm{~cm}$. One-way ANOVA test showed that BD was significantly different $(P=0.00)$ at different soil depths.

\section{Soil organic carbon (SOC)}

Our measurements showed that fire increased the amount of soil organic carbon. Compared to CON, the SOC was significantly higher after fire (fig.6). However, compared with $\mathrm{SOC}$ in different depths, SOC stock was gradually decreased with increasing soil depths except in top soil of HFHI. The SOC was highest $\left(246.07 \pm 35.75\right.$ t.ha $\left.^{-1}\right)$ at top soil of HFMI followed by HFMI $\left(220.68 \pm 29.98\right.$ t.ha $\left.^{-1}\right)$ at $2-10 \mathrm{~cm}$ depths. In case of HFHI the SOC stock $(133.0 \pm 23.66$ t.ha $\left.^{-1}\right)$ in top soil was less than other fired sites. The lowest value $\left(79.58 \pm 19.43\right.$ t.ha $\left.^{-1}\right)$ was recorded at $>30 \mathrm{~cm}$ in $\mathrm{CON}$ site (fig.6). There was significant difference $(P=0.00)$ between the sites and different soil depths tested by one-way ANOVA.

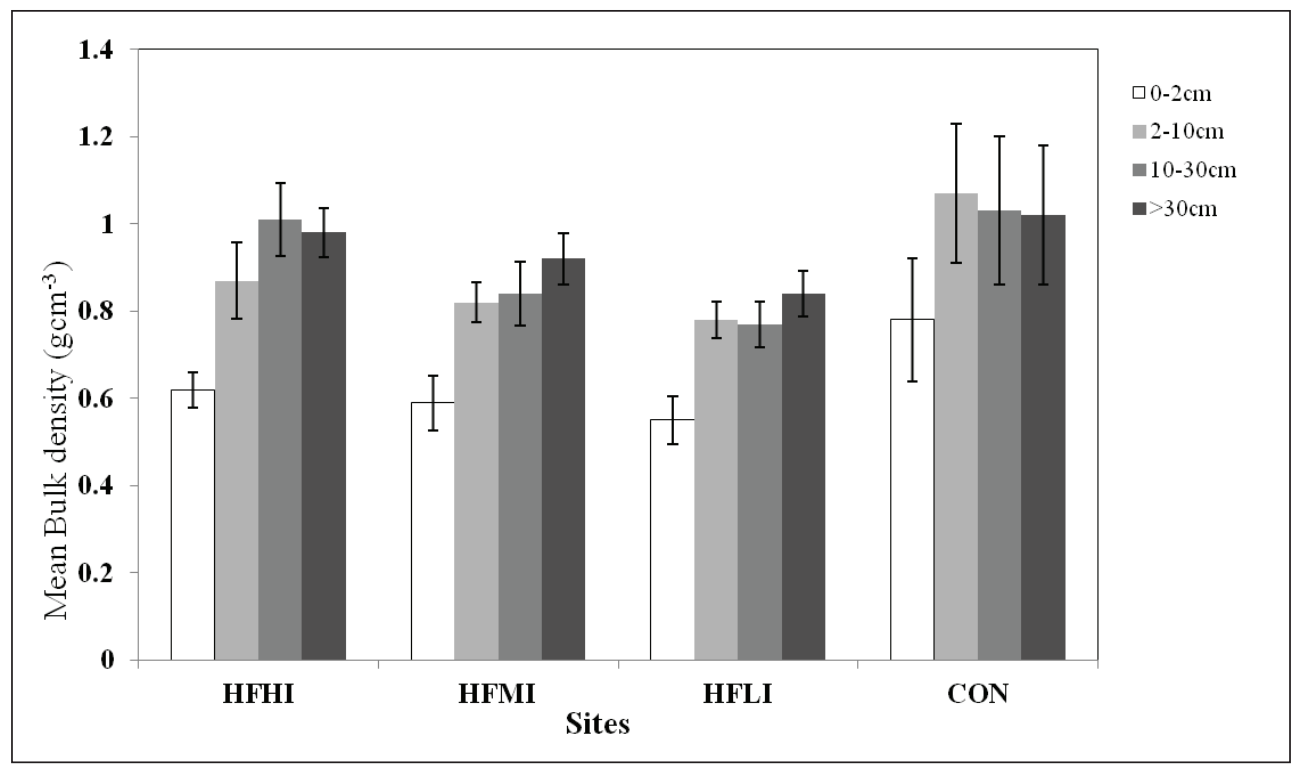

FIG. 5. Bulk density of different soil depths from all sites. Different letters denote highly significant difference between soil depths tested by Duncan multiple range test at $P \leq 0.05$. Error bar showing $\pm \mathrm{SE}(7-10)$. 


\section{Soil charcoal stock (SCS)}

Overall total charcoal stock (\%) was decreased with increasing depths of the soil of all fired sites. Total soil charcoal stock (SCS) was higher (53\%) in the top soil and lower (42\%) in 10$30 \mathrm{~cm}$ depth (fig.7). The charcoal distribution within the same fired site as well as between different fired sites showed more or less same except HFMI. In HFMI, the charcoal stock showed increased trend with increasing soil depths. The highest amount of SCS $(0.24 \pm 0.06$ t.ha $^{-1}$ ) was recorded in deep layer $(10-30 \mathrm{~cm}$ ) of HFMI (fig.8). The amount of SCS was observed negligible $\left(0.014 \pm 0.0 \mathrm{t}^{-h^{-1}}\right)$ in CON. There were no charcoals reported in the depths of $>30 \mathrm{~cm}$ in all sites. The SCS significantly differed $(P=0.00)$ at different soil depths.

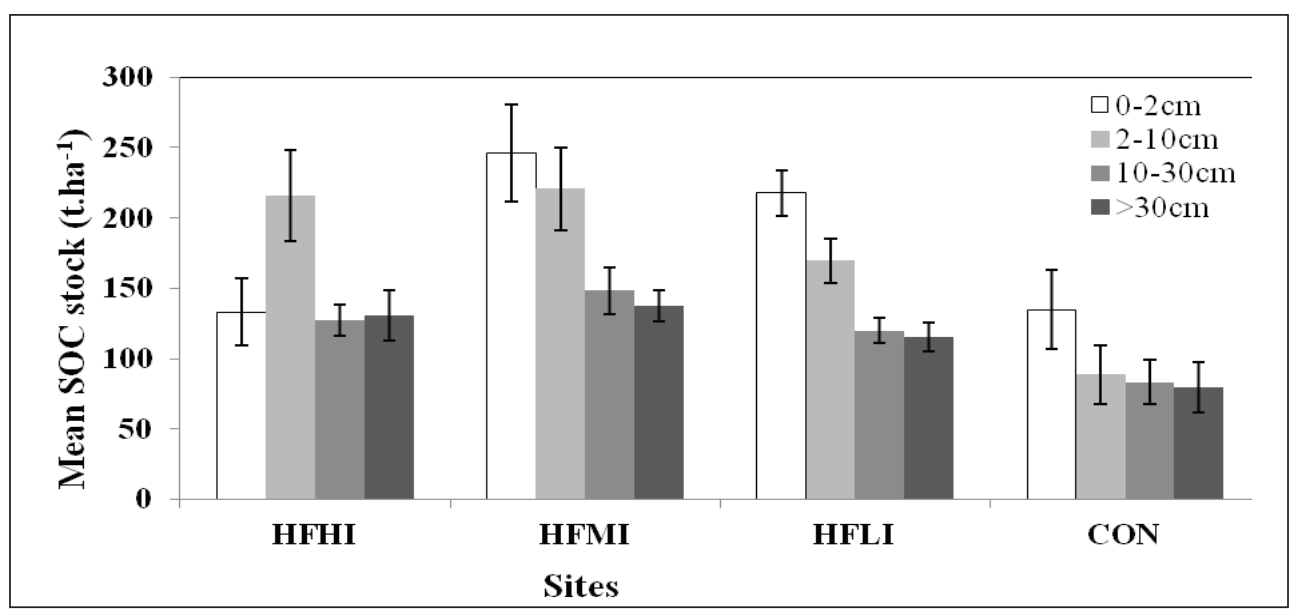

FIG. 6. Mean total SOC from all sites and soil depths. Different letters denote significant difference tested by Duncan multiple range tests at $(P<0 \nmid 95)$. Error bar indicates $\pm S E(N=4-10)$.

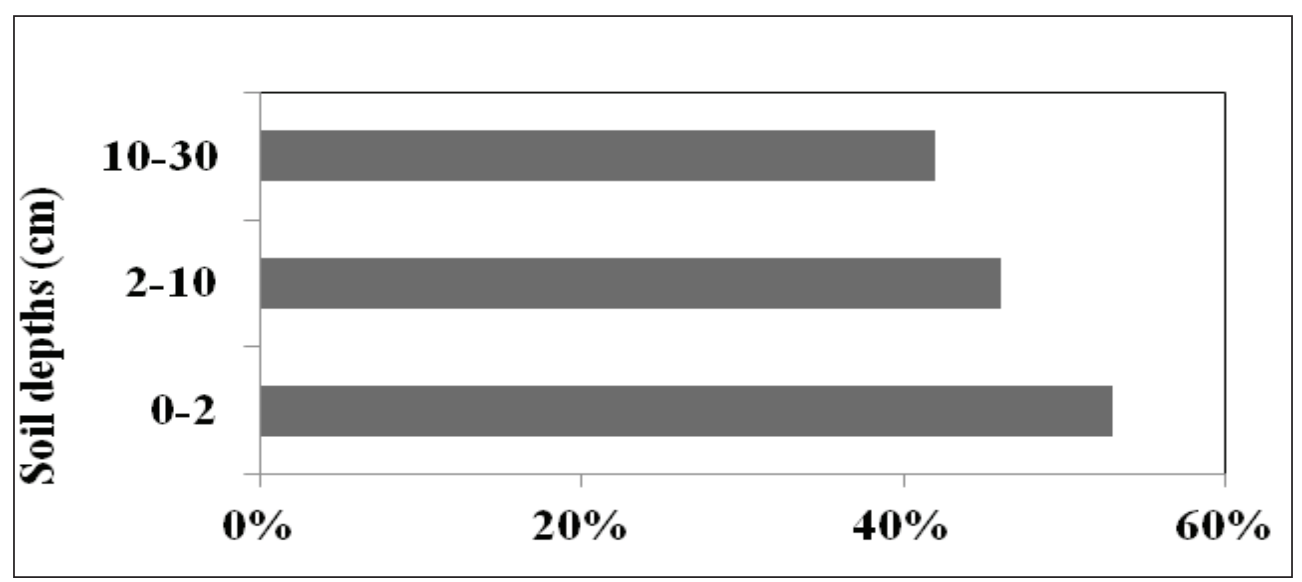

FIG. 7. Total charcoal stock (\%) of all fired sites. 


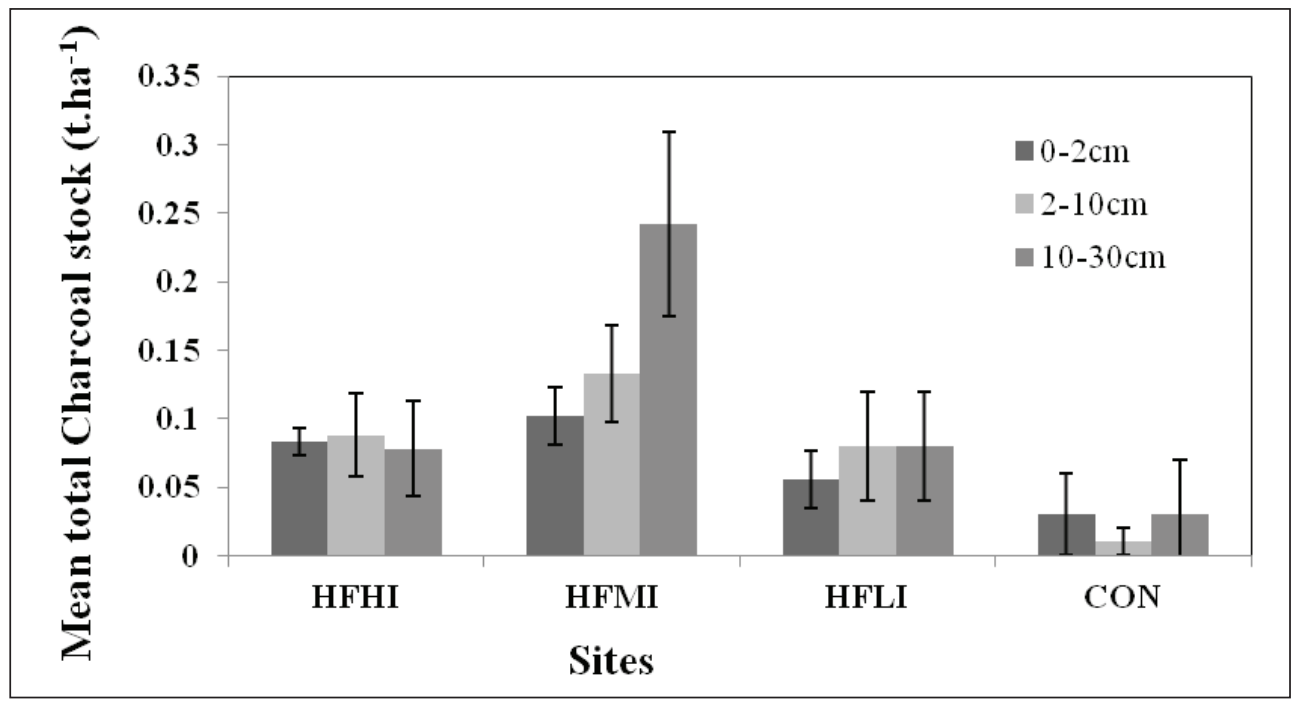

FIG. 8. Total charcoal stock (t.ha-1) from different sites and depths. Different letters denote significant difference tested by Duncan multiple range tests at $(P<0.05)$. Error bar indicates $\pm S E(N=8-10)$.

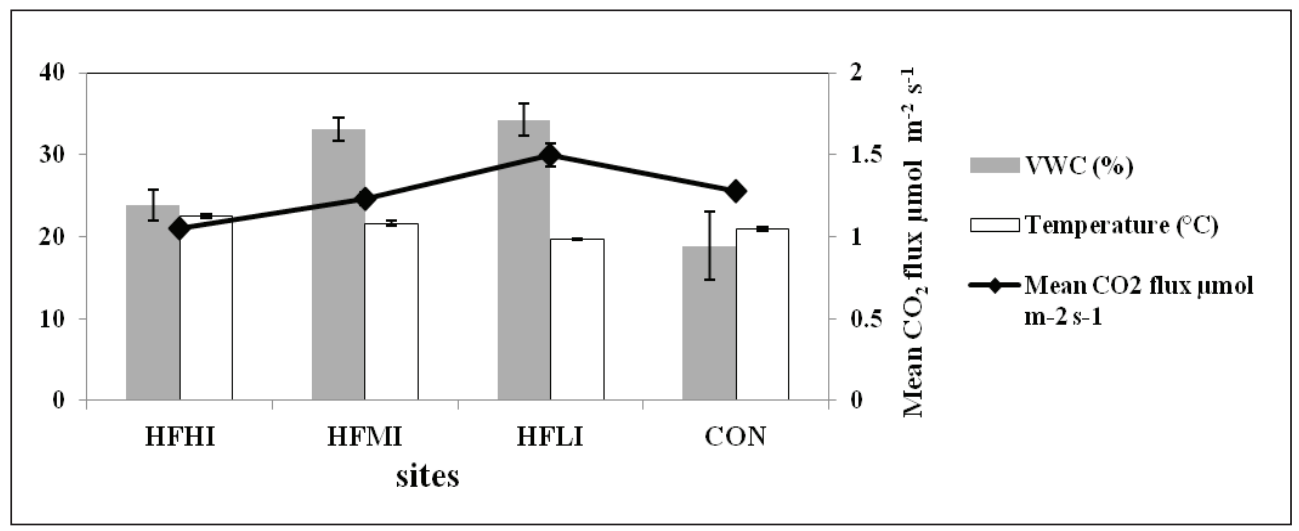

FIG. 9. Mean $\mathrm{CO}_{2}$ flux $\left(\mu \mathrm{mol} \mathrm{m} \mathrm{m}^{-2} \mathrm{~s}^{-1}\right)$, VWC $(\%)$ and ST $\left({ }^{\circ} \mathrm{C}\right)$ of different sites. Different letters denote significant difference tested by Duncan multiple range test at $(P<0.05)$. Error bar indicates $\pm \mathrm{SE}(\mathrm{N}=6-17)$. 


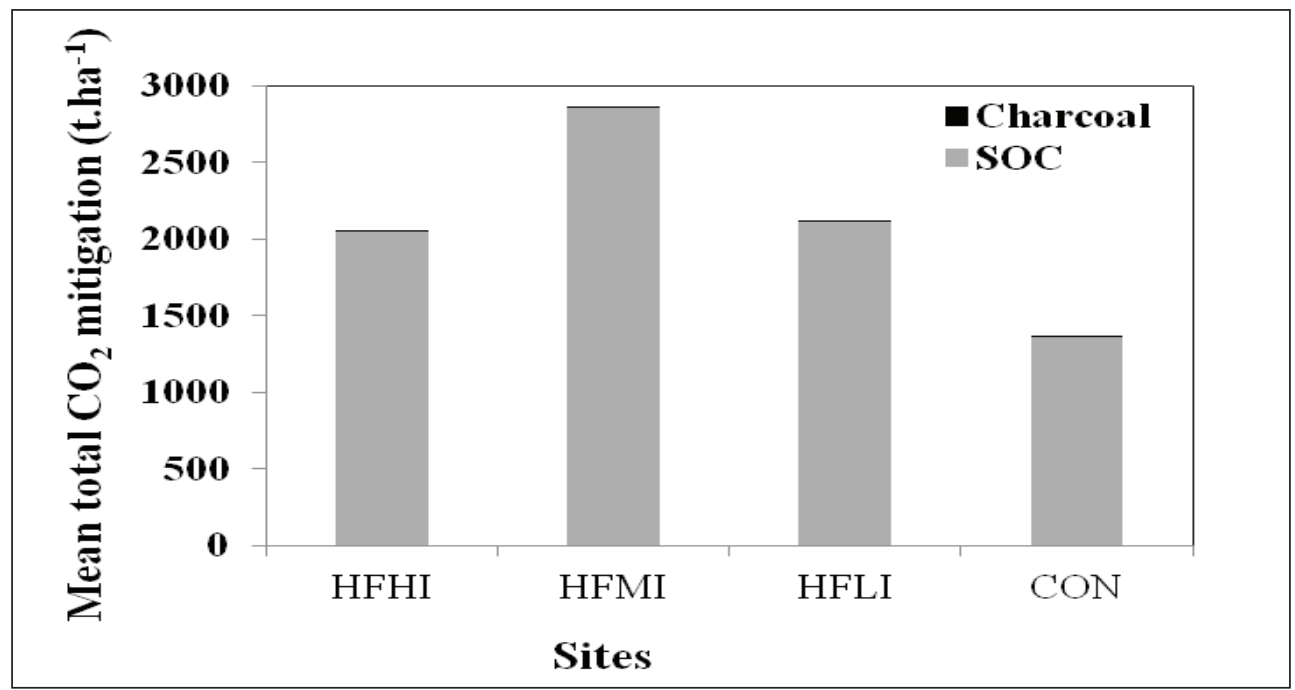

FIG.10. Mean total $\mathrm{CO}_{2}$ mitigation from different sites.

\section{Soil pH and bulk density (BD)}

Soil $\mathrm{pH}$ varies among the forest types and is generally acidic in pine forests. The $\mathrm{pH}$ remains unchanged after fire (Iglesias, 2010) while, increases due to burned vegetation and litter into the ash (Ulery et al., 1995; De Marco et al. 2004). In the present study, low to high pH value of the soil was recorded in fired and unfired (CON) sites respectively. The result suggested that soil $\mathrm{pH}$ decreases after floor fire in case of $P$. roxburghii forest.

The Bulk density depends on several factors such as compaction, consolidation and amount of SOC present in the soil but it is highly correlated to the organic carbon content (Leifeld et al., 2004; Morisada et al., 2004). The low value of BD explains less compacted soil with high pore space compared to other soil depths suitable for vegetation growth. However, high BD value makes the soil unfit for vegetation growth. The values of bulk density in all four sites at different depths were significantly different, i.e., low BD in top soil and high BD in depths. The values of $B D$ in between the sites at different depths were differed insignificantly. The pattern of BD in natural forest and fired forest are more or less similar. The possible explanation of low BD on top soil of $P$. roxburghii forest affected by floor fire may be due to decomposed biomass and the remains of burnt biomass including charcoal and other materials.

\section{Soil organic carbon (SOC)}

The total soil organic carbon is considered as the soil carbon sequestration. The findings of this study suggested that the SOC stock significantly increased after fire is consistent with the results from studies conducted at black pine plantation forest in Turkey (Kara \& Bolat, 2009), Brushland, Mediterranean environments in NE Spain (Pardini et al., 2004). However, in the contrary, decreased SOC after fire have been reported at subtropical forest in Manipur, India (Sithou \& Singh, 2014), P. roxburghii, Chir pine forest in Gharwal Himalaya, India (Kumar et al., 2013). The effect of fire on SOC abundance in an ecosystem depends on the type and frequency of fire as well as time 
and season of the burn (Zhao et al., 2012) and the availability of fuel mass, vegetation type, topography coupled with post fire climate conditions (Semwal \& Mehta, 1996). Furthermore, SOC stock gradually decreases when soil depths increases (Smith et al., 2000; Awasthi et al., 2005).

The prersent results showed the highest SOC stock at top soil of all sites except HFHI, however, the amount was significantly different among the four sites and increases with the increase of fire intensity. Ansley et al. (2006) also reported that the increased SOC was largely due to increased aboveground production (biomass) and very fine roots of grasses that may have passed through sieve in fire treatment soils. The low value of SOC in HFHI was probably due to the topography of the site (steep slope, less biomass) which allows surface washed off of charcoal and other burnt plant parts. The SOC up to $10 \mathrm{~cm}$ depth showed insignificant difference between the HFHI and HFMI, and significantly lower value in HFLI and CON suggested the possibility of leaching. Similarly, soil depths $>10 \mathrm{~cm}$ in fired sites with high SOC value suggested continuous leaching of char after annual seasonal fire than in CON site. Smith et al. (2000) and Awasthi et al. (2005) also reported low SOC at the top layer of steep slopes and high deposition in deep layers up to the $15 \mathrm{~cm}$ due to leaching.

\section{Soil charcoal stock (SCS)}

In the present study area, forest floor contained charcoal particles along the soil vertical profile up to $30 \mathrm{~cm}$ depths indicated fire disturbances. The total percentage of charcoal stock in three different soil layers, i.e. $0-2,2-10$ and $10-30 \mathrm{~cm}$ depths showed gradual decrease from top to downwards. Similar scenarios (greater amount of charcoal near the surface and lesser with increased depths) were reported by Hart et al. (2008) at mixed hardwood forest of U.S. and Amazonian seasonal forest in Brazil by Turcios et al. (2015).

Among the three fired sites, highest value of SCS was recorded in HFMI and lowest in $\mathrm{HFHI}$ from 0 to $30 \mathrm{~cm}$. The unexpected lowest value of SCS in HFHI suggested two possibilities; one is steepness of the slope $\left(40-47^{\circ}\right)$ which accelerates surface runoff and easily washed away the available charcoal, and the second is less charcoal leaching. Similarly, the high value of charcoal in HFMI was possibly due to gentle slope which supports accumulation on the top layer as well as leaching in course of time. However, the negligible amount of charcoal accumulation in CON has been possible by wind, water, landslides, etc., from surrounding fired ecosystems. Suman (1984) suggested that charcoal leaching is one of the excellent examples of long term $C$ pool and past fire condition. Surface charcoal can washed away by monsoon but charcoal in the soil depths were deposited for as long term. Similar findings were recorded including charcoal deposition (Horn \& Underwood, 2014) and relationship between fire, climate, and human activity to document past fires (Horn et al., 2000; League \& Horn, 2000; Sanford \& Horn, 2000; Whitlock \& Larsen, 2001; Berg \& Anderson, 2006; Hart et al., 2008). Our mean total data of SCS was much less than the previous work done in Colorado subalpine forest where the charcoal carbon pool was estimated $1.5 \mathrm{Mg} / \mathrm{ha}$ for Ponderosa pine, $1.2 \mathrm{Mg} / \mathrm{ha}$ for Lodgeopole pine from the surface soil $(0-10 \mathrm{~cm})$ (Licata \& Sanford, 2012). It is suggested that the P. roxburghii forest of the Langtang National Park was mainly influenced by forest floor fire rather than extensive fire. 


\section{$\mathrm{CO}_{2}$ flux, volumetric water content and soil temperature}

$\mathrm{CO}_{2}$ flux from soils have been shown to be a useful measure of the relative biological phenomenon to understand the sum of the total activity of microbial, microfaunal, mycorrhizal, mosses, and root respiration (Weber, 1990). In this study, $\mathrm{CO}_{2}$ flux increased with the increase of VWC of the soil in all sites. Raich \& Schlesinger (1992) and Burke \& Zepp (1997) obtained similar results in major vegetation biomes and Canadian boreal forest, respectively. Raich \& Schlesinger (1992) observed strong positive correlation between air temperature and $\mathrm{CO}_{2}$ flux in all major biomes; $\mathrm{CO}_{2}$ flux increases with increase of air temperature from -15 to $30^{\circ} \mathrm{C}$. In present study, the sites were located at the almost same altitude (sub-tropical) with minor microclimatic differences. The soil temperature recorded was in decreasing trend ranged from 22.5 to $19.8^{\circ} \mathrm{C}$ with the increase of fire intensity. However, the temperature variation was almost negligible. Among the three fired sites, the intensity of fire decreased from $\mathrm{HFHI}<\mathrm{HFMl}<\mathrm{HFLI}$ leading to decreased floor biomass and ultimately $\mathrm{CO}_{2}$ flux. Therefore the high $\mathrm{CO}_{2}$ flux in $\mathrm{HFLI}$ was may be due to the accumulation of relatively high floor biomass than other two fired sites. It is suggested that variation of $\mathrm{CO}_{2}$ flux not only depends on the volumetric water content and temperature as in natural ecosystems, additionally depends on the intensity of fire as well.

\section{$\mathrm{CO}_{2}$ mitigation}

Forest fire sinks carbon in the form of soil organic carbon and soil charcoal.Capacity of $\mathrm{CO}_{2}$ mitigation may vary among the different forest soil. In our study, total $\mathrm{CO}_{2}$ mitigation of soil was found highest in HFMI, medium in HFHI and HFLI, and lowest in CON site. The highest $\mathrm{CO}_{2}$ mitigation in HFMI and then other fired sites suggested that $P$. roxburghii forest fire of any intensity limited to the forest floor has positive impact although amount of $\mathrm{CO}_{2}$ released during the fire was not been calculated.

In Langtang National Park annual forest fire is only limited to the forest floor with different intensities. During the forest floor fires, a significant amount of $\mathrm{CO}_{2}$ is emitted to the atmosphere. Simultaneously, a fraction of the burning vegetation and soil organic matter is converted into charcoal. Different fire intensities yield different quantities of charcoal thus removing the carbon from faster cycling carbon pools and accumulating in soils for a long time, which helps to increase the rate of $\mathrm{CO}_{2}$ mitigation ultimately reducing $\mathrm{CO}_{2}$ from the environment. Finally, fire of medium intensity showed high $\mathrm{CO}_{2}$ mitigation showing positive impacts. Therefore, it is concluded that the controlled forest floor fire is beneficial to the global carbon mitigation at least in our case. Therefore, regular monitoring of this forest is necessary to induce control fire in manage form to increase $\mathrm{CO}_{2}$ mitigation by increasing sequestration of the area as well as long term carbon pool.

\section{ACKNOWLEDGEMENTS}

This paper is based on research funded under the Climate Change Research Grants Program implemented by the Nepal Academy of Science and Technology (NAST), Khumaltar, Lalitpur, Nepal. The Program was a part of the Mainstreaming Climate Change Risk Management in Development project. This project was a component of Nepal's Pilot Program for Climate Resilience executed by the Ministry of Population and Environment (Nepal), financed by the Climate Investment Funds, administered by the Asian Development Bank with technical assistance from ICEM, METCON and APTEC. The authors are thankful to the DNPWC and 
Park authorities for providing permission for field work. Authors are also thankful to the members of "Society for Natural Resources conservation and development", Gyanendra Neupane (Journalist, Rasuwa), Ram Ranabhat (Birendra Multiple Campus, Bharatpur) and Sushma Devkota for supporting during this study.

\section{REFERENCES}

ANSLEY, R J; BOUTTON, T W; SKJEMSTAD, J O (2006) Soil organic carbon and black carbon storage and dynamics under different fire regimes in temperate mixed-grass savanna. Global Biogeochemical Cycles 20:1-11.

ARMOUR, C D; BUNTING, S C; NEUENSCHWANDER, L F (1984) Fire intensity effects on the understory in Ponderosa Pine forest. Journal of Range Management 37:44-49.

AWASTHI, K D; SINGH, B R; SITAULA, B K (2005) Profile carbon and nutrient levels and management effect on soil quality indicators in the Mardi watershed of Nepal. Acta agriculture Scandinavia Section B-soil and plant 55:192-204.

BAJRACHARYA, R M; LAL, R; KIMLE, J M (1998) Soil process and the carbon cycle: long term tillage effect on soil organic carbon distribution in aggregates and primary particles fractions of two ohio soils. In LAL, R; KIMBLE, J M; FOLLETT, R F; STEWART, B A (eds) Soil process and the carbon cycle. CRC Press, Boca, Raton, FL, USA; pp 353-368.

BERG, E E; ANDERSON, R S (2006) Fire history of white and Lutzspruce forests on the Kenai Peninsula, Alaska, over the last two millennia as determined from soil charcoal. Forest ecology and management 227: 275-283.

BHATTARAI, T P; SKUTSCH, M; MIDMORE, D J; RANA, E B (2012) The carbon sequestration potential of community-based forest management in Nepal. International Journal of climate change 3: 233-251.

BLAKE, G R; HARTGE, K H (1986) Bulk density. In KLUTE, A (ed) Methods of soil analysis, Part 1. Agron. Monogr. 9. ASA and SSSA, Madison, Wl; pp 363-375 (2nd ed).

BURKE, R A; ZEPP, R G; TARR, M A; MILLER, W L; STOCKS, B J (1997) Effect of fire on soil-atmosphere exchange of methane and carbon dioxide in Canadian boreal forest sites. Journal of Geophysical Research - Atmospheres 102: 29289-29300.

DE MARCO, A; GENTILE, A E; ARENA, C; DE SANTO, A (2004) Nutrient content and biological activity in burned and unburned soils of a Mediterrabean maquis area of southern Italy. Geophys Eur Geosci Un Res Abstr 6: 06999.

DRUFFEL, E R M (2004) Comments on the importance of black carbon in the global carbon cycle. Marine Chemistry 92:197-200.

FEARNSIDE, P M; GRACA, P M L A; RODRIGUES, F J A (2001) Burning of Amazonian rainforest: burning efficiency and charcoal formation in forest cleared for cattle pasture near Manaus, Brazil. Forest Ecology and Management 146:115-128.

FIRE SCIENCE BRIEF (2009) Low-intensity fire in eastern white pine. A supporting role in understory diversity. 52: (www.firescience.gov).

FOEREID, B; LEHMANN, J; MAJOR, J (2011) Modeling black carbon degradation and movement in soil. Plant and Soil 345:223-236.

FORBES, M S; RAISON, R J; SKJEMSTAD, J O (2006) Formation, transformation and transport of black carbon (charcoal) in terrestrial and aquatic ecosystems. Science of the Total Environment 370:190-206. 
HART, J L; HORN, S P; GRISSINO-MAYER, H D (2008) Fire history from soil charcoal in a mixed hardwood forest on the Cumberland Plateau. Journal of the Torrey Botanical Society 135: 401-410.

HORN, S P; UNDERWOOD, C A (2014) Methods for the study of soil charcoal as an indicator of fire and forest history in the Appalachian region. In WALDROP, T A (ed) Proceedings of wildland fire in the Appalachians; discussions among managers and scientists. Gen.Tech.Rep.SRS-199. US Department of Agriculture Forest Service, Southern Research Station, Asheville, NC, USA; pp 104-110.

HORN, S P; ORVIS, K H; KENNEDY, L M; CLARK, GM (2000) Prehistoric fires in the highlands of the Dominican Republic: evidence from charcoal in soils and sediments. Caribbean Journal of Science 36:10-18.

HOUGHTON, K A; WOODWELL, G M (1989) Global climate change. Scientific American 260:36-44.

IGLESIAS, M T (2010) Effects of fire frequency on nutrient levels in soils of Aleppo pine forest in southern France. Lazaroa 31:147-152.

JAMES, E L; LEON, K B; .NEUENSCHWANDER, F (1985) Role of fire in Lodgepole pine forests. In BAUMGARTNER, D M; KREBILL, R G; ARNOTT, J T; WEETMAN, G F (eds) Lodgepole pine the species and its management symposium proceedings. Washington State University, Pullman, USA; pp 133-152.

KARA, O; BOLAT, I (2009) Short-term effects of wildfire on microbial biomass and abundance in black pine plantation soils in Turkey. Ecological Indicators 9:1151-1155.

KIRSHBAUM, M U F (2000) Will changes in soils organic carbon act as a positive or negative feedback on global warming? Biogeochemistry 48:21-51.

KUHLBUSCH, T; CRUTZEN, P J (1995) Toward a global estimate of black carbon in residues of vegetation fires representing a sink of atmospheric $\mathrm{CO}_{2}$ and a source of $\mathrm{O}_{2}$. Global Biogeochemical Cycles 9:491-501.

KUMAR, M (2015) Carbon stock in standing dead trees of Pinus roxburghii Sarg. in sub-tropical part of Garhwal Himalaya. Forestry Ideas 21:75-83.

KUMAR, M; SHEIKH, M.A; BHAT, J.A; BUSSMANN, R W (2013) Effect of fire on soil nutrients and under story vegetation in Chir pine forest in Garhwal Himalaya, India. Acta Ecologica Sinica 33:59-63.

LAL, R; KIMBLE, J M; FOLLETT, R F; COLE, C V (1998) The potential of US cropland to sequester carbon and mitigate the greenhouse effect. Sleeping Bear Press, Chelsea, Michigan, USA; $128 \mathrm{p}$.

LAL, R; KIMBLE, J M (1997) Conservation tillage for carbon sequestration. Nutrient Cycling in Agro ecosystems 49:243-253.

LAL, R J; KIMBLE, M; STEWART, B A (1995) World soils as a source or sink for relatively active gases. In LAL, R; KIMBLE, J; LEVINE, E; STEWART, B A (eds) Soil management and greenhouse effect. Lewis Publisher, Boca Raton, Florida, USA; pp 1-8.

LEAGUE, B L; HORN, S P (2000) A 10,000 year record of páramo fires in Costa Rica. Journal of Tropical Ecology 16: 747-752.

LEIFELD, J; BASSIN, S; FUHRER, J (2004) Carbon stock in Swiss agriculture soils predicted by land use soil characteristics, and altitude. Agriculture, Ecosystem and Environment 105: 255-266.

LICATA, C; SANFORD, R (2012) Charcoal and total carbon in soils from foothills shrublands to subalpine forests in the Colorado front range. Forests 3:944-958.

MARLAND, G; ROTTY, R M (1984) Carbon dioxide emissions from fossil fuels: a procedure for estimation and results for 1950-1982. Tellus 36:232-261.

MORISADA, K; ONO, K; KANOMATA, H (2004) Organic carbon stock in forest soils in Japan. Geoderma 119: $21-32$. 
PARDINI, G; GISPERT, M; DUNJO, G (2004) Relative influence of wildfire on soil properties and erosion processes in different Mediterranean environments in NE Spain. Science of the Total Environment 328:237-246.

PATTERSON, W A; EDWARDS, K J; MAGUIRE, D J (1987) Microscopic charcoal as an indicator of fire. Quaternary Science Review 6:3-23.

PAUDYAL, D (2008) Sustainable resin tapping in Nepal: challenges and opportunities (a case from Salyan districs). The initiation 2:172-179.

PEARSON, T R H; BROWN, S; RAVINDRANATH, N H (2005) Integrating carbon benefit estimates into GEF projects. Capacity Development and Adaptation Group Guidelines. United Nations Development Programme, Global Environment Facility, Bureau of Development Policy, New York, USA.

RAICH, J W; SCHLESINGER, W H (1992) The global Carbon dioxide flux in soil respiration and its relationship to vegetation and climate. Tellus 44B:81-99.

RASSE, D P; MULDER, J; MONI, C; CHENU, C (2006) Carbon turnover kinetics with depth in a French loamy soil. Soil Science Society of American Journal 70:2097-2105.

SANFORD Jr, R L; Horn, S P (2000) Holocene rain-forest wilderness: a neotropical perspective on humans as an exotic, invasive species. In COLE, D N; MCCOOL, S F; BORRIE, W T; O'LOUGHLIN; COMPS, J (eds) Proceedings of wilderness science in a time of change, Vol. 3. U.S. Department of Agriculture, Forest Service, Rocky Mountain Research Station, Ogden, Utah, USA; pp 68-173.

SCHMIDT, M W I (2004) Carbon budget in the black. Nature 427: 305-306.

SEILER, W; CRUTZEN, P J (1980) Estimates of gross and net fluxes of carbon between the biosphere and the atmosphere from biomass burning. Climatic Change 2:207-247.

SEMWAL, R L; MEHTA, J P (1996) Ecology of forest fires in Chir Pine (Pinus roxburghii Sarg.) forests of Garhwal Himalaya. Current Science 70:426-427.

SITLHOU, A; SINGH, T B (2014) Post-fire nutrient availability in the sub- tropical forest ecosystem of the Koubru Hills, Manipur, India. F1000 Research 3(30): 1-19.

SMITH, P; POWLSON, D S; SMITH, J U; FALLOON, P; COLEMAN, K (2000) Climate change commitments: quantitative estimates of the potentials for carbon mitigation by agriculture. Global Climate Change 6:525-539.

SUMAN, D O (1984) The production and transport of charcoal formed during agricultural burning in central Panama. Interciencia 9:311-313.

TURCIOS, M M; JARAMILLO, M M A; DOVALEJR, J; FEARNSIDE, P M; BARBOSA, R I (2016) Soil charcoal as long-term pyrogenic carbon storage in Amazonian seasonal forests. Global change Biology 22:190-197.

ULERY, A L; GRAHAM, R C; CHADWICK, O A; WOOD, H B (1995) Decade scales changes of soil carbon, nitrogen exchangeable cations under chaparral and pine. Geoderma 65:121-134.

WHITLOCK, C; LARSEN, C (2001) Charcoal as a fire proxy. In SMOL, J P; BIRKS, H J B; LAST, W M (eds) Tracking environmental change using lake sediments: terrestrial, algal, and siliceous indicators, Volume 3. Kluwer Academic Press, Dordrecht, The Netherlands; pp 75-97.

ZHAO, H; TONG, D Q; LIN, Q; WANG, G (2012) Effect of fires on soil organic carbon pool and mineralization in a northeastern China wetland. Geoderma 189-190:532-539. 